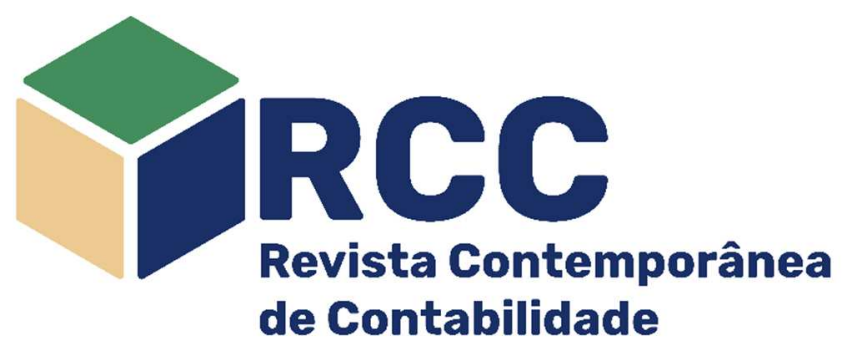

\title{
Reflexões sobre as bases filosóficas dos princípios contábeis
}

\author{
Reflections of the philosophical basis of accounting principles \\ Reflexiones sobre la base filosófica de los principios contables
}

Sérgio de ludícibus
Doutor em Controladoria e Contabilidade pela FEA (USP)
Professor de Mestrado, Faculdade de Economia,
Administração, Contabilidade e Atuária, Departamento de
Contabilidade (PUC/SP), São Paulo, SP - Brasil
Professor Emérito da Faculdade de Economia,
Administração, Contabilidade da Universidade - FEA
(USP), São Paulo, SP - Brasil
siudicibus@pucsp.br
https://orcid.org/0000-0001-9657-7186 (1)
Valdemir Regis Ferreira de Oliveira*
Mestre em Contabilidade (UnB)

\author{
Jorge Katsumi Niyama \\ Doutor em Controladoria e Contabilidade pela FEA (USP) \\ Professor da Faculdade de Economia, Administração, \\ Contabilidade e Gestão Pública - FACE \\ (UnB), Brasília, DF - Brasil \\ jorgekatsumi@gmail.com \\ https://orcid.org/0000-0002-8738-3838 (1)
}

Ilse Maria Beuren

Doutora em Controladoria e Contabilidade pela FEA (USP) Professora do Programa de Pós-Graduação em Contabilidade (UFSC), Florianópolis, SC - Brasil ilse.beuren@gmail.com https://orcid.org/0000-0003-4007-6408

Endereço do contato principal para correspondência* Campus Universitário Darcy Ribeiro, Prédio da FACE, Asa Norte, CEP: 70910-900 - Brasília, DF - Brasil

\section{Resumo}

Desde a antiguidade a filosofia tem se valido do estudo do pensamento, da razão, da verdade, da ética e do conhecimento que permeiam os ramos da ciência. A Teoria da Contabilidade, quando estudada sob a abordagem ética, deveria apresentar-se como justa e não enviesada para todos os interessados. Os princípios no âmbito da Teoria da Contabilidade não são uniformes, sendo evidenciados nas estruturas conceituais e normas dos países segundo sua cultura, costumes, valores éticos e sistemas jurídicos. Assim, tomando por partida as raízes italianas do método das partidas dobradas (berço da contabilidade), analisa-se as bases filosóficas dos princípios contábeis no Brasil e na França (berço do lluminismo). Por meio de um ensaio teórico de caráter crítico-argumentativo revela-se que por trás dos conceitos definidos nos princípios contábeis encontram-se fundamentações teórico-filosóficas. Conclui-se que os princípios contábeis, em sua concepção, coadunam-se aos pressupostos filosóficos da ética, da moral e da busca pela verdade.

Palavras-chave: Princípios Contábeis; Bases filosóficas; Teoria da Contabilidade

\begin{abstract}
Since ancient times philosophy has used the study of the thought, reason, truth, ethics and knowledge that permeate the branches of science. Accounting Theory, when studied under the ethical approach, should be fair and not biased to all concerned. The principles within the Accounting Theory are not uniform, being evidenced in the conceptual structures and norms of countries according to their culture, customs, ethical values and legal systems. Thus, taking as its starting point the Italian roots of the double-entry method (cradle of accounting), we analyze the philosophical bases of accounting principles in Brazil and France (cradle of the Enlightenment). Through a critical-argumentative theoretical essay it is revealed that behind the concepts defined in the accounting principles there are theoretical-philosophical foundations. It is concluded that accounting principles, in their conception, fit the philosophical assumptions of ethics, morals and the search for truth.
\end{abstract}

Keywords: Accounting principles; Philosophical bases; Accounting Theory 


\section{Resumen}

Desde la antigüedad, la filosofía ha utilizado el estudio del pensamiento, la razón, la verdad, la ética y el conocimiento que impregnan las ramas de la ciencia. La Teoría de la Contabilidad, cuando se estudia bajo el enfoque ético, debe ser justa y no sesgada para todos los interesados. Los principios dentro de la Teoría de la Contabilidad no son uniformes, y se evidencian en las estructuras conceptuales y las normas de los países de acuerdo con su cultura, costumbres, valores éticos y sistemas legales. Así, tomando como punto de partida las raíces italianas del método de doble entrada (cuna de la contabilidad), analizamos las bases filosóficas de los principios de contabilidad en Brasil y Francia (cuna del lluminismo). A través de un ensayo teórico críticoargumentativo se revela que detrás de los conceptos definidos en los principios contables se encuentran los fundamentos teóricos y filosóficos. Se concluye que los principios contables, en su concepción, se ajustan a los supuestos filosóficos de la ética, la moral y la búsqueda de la verdad.

Palabras clave: Principios contables; Bases filosóficas; Teoría de la Contabilidad

\section{Introdução}

A filosofia tem se valido do estudo do pensamento, da razão, da verdade, da ética e do conhecimento das coisas que permeiam todos os ramos da ciência. No entanto, nem mesmo a concepção do termo verdade tem sido objeto de consenso entre os filósofos, pois segundo Protágoras (490-420 a.C), a verdade é relativa por ser uma opinião subjetiva, depende da perspectiva de cada pessoa (DURANT, 1996). Desse modo, a interdisciplinaridade entre os diversos ramos da ciência assimilou em seus constructos teóricos diferentes estudos e manifestações de filósofos ao longo do tempo.

Nesta perspectiva, a Teoria da Contabilidade pode ser estudada sob diversas abordagens. ludícibus (2010) esclarece que sob a abordagem ética, a contabilidade deveria apresentar-se como justa e não enviesada para todos os interessados. Sob a abordagem comportamental, explica que as informações contábeis deveriam ser produzidas sob medida, de forma que os usuários reajam para o correto processo decisório (atinge os campos da psicologia, da sociologia e da economia), com maior ênfase na forma de uso dos relatórios contábeis do que no desenvolvimento lógico dos demonstrativos. Sob a abordagem sociológica, assevera que a contabilidade é julgada por seus efeitos no campo social. Trata-se de uma abordagem do tipo bem-estar social (welfare).

Desde Luca Pacioli (1445-1517), considerado o pai da contabilidade e precursor do método das partidas dobradas ou método veneziano, em seu livro Summa de Arithmetica (1494), a Ciência Contábil tem se preocupado com a veracidade dos registros e expressão da verdade do fato contábil. A filosofia italiana, enquanto lócus embrionário da contabilidade, revelou pensadores e estudiosos como Fábio Besta (18451922), filósofo e professor da escola italiana de contabilidade, cujas obras La Ragioneria - Prolusioni (1880) e La Ragioneria - Volumi I, II e III (1891-1916), conferiram às raízes da Ciência Contábil dimensão científica a partir do início do século XIX, resultando no desenvolvimento da Teoria da Contabilidade baseado na realidade e nos fatos observáveis (PAOLINI; SOVERCHIA, 2017).

No mundo contemporâneo, a Ciência Contábil incorpora um grande número de teorias intermediárias (middle-range theories) cujo teor preditivo e explicativo limita-se a um subconjunto dos fenômenos contábeis (RIAHI-BELKOUI, 2004). Uma teoria compreende "um conjunto de constructos (conceitos), definições e proposições inter-relacionados que apresentam uma visão sistemática do fenômeno, especificando relações entre variáveis com o objetivo de explicar e prever os fenômenos" (RIAHI-BELKOUI, 2004, p. 83).

A Ciência Contábil sustenta-se em princípios. Byrne (1937) e May (1937) afirmam que os princípios são verdades fundamentais; uma lei ou doutrina abrangente, da qual outras decorrem, ou nas quais outras estão baseadas; uma verdade geral; uma proposição básica ou premissa fundamental; uma máxima; um axioma; um postulado. São, portanto, uma lei ou regra geral considerada como diretriz de ação; uma base aceita de conduta ou prática. Há que se diferenciar os princípios em sua concepção filosófica das concepções legais definidas nas estruturas conceituais do regramento contábil.

A estrutura conceitual da contabilidade define os conceitos fundamentais de relatórios financeiros ou contábeis e funciona como orientação no desenvolvimento de padrões das normas internacionais de contabilidade, segundo o International Accounting Standards Board (IASB, 2010). Para o desenvolvimento de suas estruturas conceituais, os países baseiam-se em argumentos normativos, os quais se referem ao que deveriam ser (contém juízo de valor, subjetivo); ou argumentos positivos, os quais se referem ao que realmente são (respeitam os cânones científicos, objetivistas) (NUNES, 2012).

Estruturas conceituais baseadas em regras geralmente possuem caráter operacional e são direcionadas aos mecanismos de escrituração contábil. Já as estruturas conceituais fundamentadas em princípios costumam ter embasamentos filosóficos e norteadores de conduta e de valores dos agentes da profissão contábil, bem como da ética, da moral e da true and fair view enquanto pressupostos das transações e escriturações. No entanto, tal qual para a filosofia não há verdade absoluta, pois depende da perspectiva de cada pessoa, os princípios no âmbito da teoria da contabilidade não são uniformes e geralmente pautados nas estruturas conceituais e regulamentos de países segundo sua cultura, costumes, valores éticos de seu povo e sistemas jurídicos predominantes. O sistema legal de cada país é moldado por sua história única e, portanto, incorpora variações individuais (WOOD, 1980). 
O Financial Accounting Standards Board (FASB, 2002, p. 10) aduz que "uma abordagem focada mais claramente sobre os princípios em normas de contabilidade é necessária para melhorar a qualidade e transparência dos relatórios contábeis e financeiros dos EUA". Graham Ward, presidente da International Federation of Accountants (IFAC), declarou que "a profissão contábil e os profissionais de auditoria no Reino Unido e na União Europeia acreditam muito claramente que uma abordagem baseada em princípios é a correta" (PIPER, 2005, p. 64). Ressalta-se que tanto o FASB quanto o IASB têm um objetivo em comum compartilhado por seus constituintes, uma vez que "seus padrões são claramente baseados em princípios consistentes" (FASB / IASB, 2006, p. vi).

A orientação sobre pautar-se exclusivamente por uma normatização fundamentada em regras ou em padrões baseados em princípios é uma lacuna de pesquisa que instiga. A pesquisa é um processo de descoberta intelectual, que possui o potencial de transformar nosso conhecimento e entendimento do mundo ao nosso redor (RYAN et al., 2002). Para se compreender o impacto das premissas, conceitos e suposições filosóficas no processo de pesquisa, é necessário verificar dois aspectos: a própria natureza da realidade; e, a maneira pela qual o conhecimento dessa realidade é obtido (EASTERBY-SMITH et al., 1991). Nesse contexto, o presente estudo objetiva analisar os embasamentos filosóficos que norteiam os princípios contábeis no âmbito da teoria da contabilidade no Brasil e na França.

A Europa Continental, notadamente a França, é considerada o berço do iluminismo e dos grandes filósofos, logo é de se esperar que os princípios norteadores dos regramentos contábeis vigentes nesses países, e posteriormente difundidos internacionalmente, tenham sido influenciados por seus ensinamentos. Desse modo, por meio de um ensaio teórico de caráter crítico-argumentativo apresentam-se reflexões que conduzem a provocações de que por trás dos conceitos definidos nos princípios contábeis encontram-se fundamentações teórico-filosóficas mais desenvolvidas ou menos explícitas, porém norteadoras da conduta dos contadores segundo as peculiaridades históricas e culturais dos países onde estão inseridos.

A relevância da pesquisa filosófica para a contabilidade encontra amparo nas motivações apontadas por ludícibus e Martins (2015) e Hoog (2017): (i) identificar a verdade real aristotélica, que leva a um critério de moderação e de igualdade, ainda que em detrimento da forma, por ser um juízo de independência acadêmica e doutrinária, portanto, científico e legítimo; (ii) aprender a refletir e a interpretar os fenômenos patrimoniais, fato importante para se afastar ambiguidade contábil e equívocos oriundos de interpretações polissêmicas; e (iii) aprender a pensar e não no que pensar. O principal meio de conscientização é o pensamento. A atividade de pensar dá ao contador consciência lógica para conhecer a verdade real nos termos da teoria da construção do conhecimento de Piaget (1896-1980).

Nesta perspectiva, ludícibus e Martins (2015) e Hoog (2017) destacam duas outras motivações: (i) conhecer a metodologia e métodos aplicados à ciência contábil, conforme preconizado por Descartes e seu método científico; e (ii) conhecer a dedução contábil que é a operação mediante a qual se conclui que uma ou que várias proposições tomadas como premissas são verdadeiras ou são inventivas, em virtude de regras do método do raciocínio lógico-contábil, que verte da teoria pura da contabilidade. Um processo dedutivo contábil é um raciocínio no qual a forma lógica valida e garante a verdade real de uma conclusão se as premissas inspecionadas forem verdadeiras.

\section{Referencial Teórico}

\subsection{Construção do conhecimento, processo de aprendizagem e filosofia}

O processo de construção do conhecimento como meio de explicação do desenvolvimento intelectual parte da premissa de que os atos biológicos são adaptações ao meio físico e organizações do meio ambiente, em busca de equilíbrio (PIAGET, 1975). A teoria de aprendizagem piagetiana defende que o processo de maturação intelectual age do mesmo modo que o desenvolvimento biológico, não podendo, portanto, a atividade intelectiva ser dissociada do funcionamento do organismo (WADSWORTH, 1996). De acordo com Piaget (1975, p. 7), "do ponto de vista biológico, organização é inseparável da adaptação: eles são dois processos complementares de um único mecanismo, sendo que o primeiro é aspecto interno do ciclo do qual a adaptação constitui o ciclo externo".

O filósofo austríaco Ludwig Wittgenstein, contemporâneo de Piaget, desenvolveu no âmbito da filosofia da linguagem, por meio de uma abordagem lógica, sua obra publicada em 1921, intitulada Tractatus logico-philosophicus, na qual afirmava que "os limites da minha linguagem denotam os limites do mundo" (WITTGENSTEIN, 2013, p. 111). Sua lógica era que a linguagem compõe-se de proposições sobre coisas que podem ser verdadeiras ou falsas, logo, "o mundo é composto de fatos; e, as proposições são imagens de fatos do mesmo modo que mapas são imagens do mundo, então minha linguagem é, portanto, limitada a declarações de fatos sobre o mundo" (WITTGENSTEIN, 2013, p. 55). As principais contribuições desse autor foram nos campos da lógica, da filosofia da linguagem e da filosofia da matemática.

Na concepção de Piaget (1999), a aprendizagem só ocorre mediante a consolidação das estruturas de pensamento, portanto, a aprendizagem se dá após a consolidação do esquema que a suporta, da mesma forma a passagem de um estágio a outro é dependente da consolidação e superação do anterior. Segundo Piaget (1999), para ocorrer a construção de um novo conhecimento, é preciso que se estabeleça um 
desequilíbrio nas estruturas mentais, isto é, os conceitos já assimilados necessitam passar por um processo de desorganização para que possam, a partir de uma perturbação, se reorganizar, estabelecendo um novo conhecimento.

No processo da aprendizagem, Lev Vygotsky defende a dialética das interações com as pessoas e com o meio, como desencadeadora do desenvolvimento sociocognitivo. Segundo Vygotsky (1978; 2004), o desenvolvimento é impulsionado pela linguagem. Acredita-se que a estrutura dos estágios descrita por Piaget seja correta, porém difere na concepção de sua dinâmica evolutiva. Enquanto Piaget defende que a estruturação do organismo e do indivíduo precede o desenvolvimento, para Vygotsky é o próprio processo de aprendizagem que gera e promove o desenvolvimento das estruturas mentais superiores.

O método cartesiano pressupõe a simplificação no processo de aprendizagem. Dessa forma, tudo o que parece ser complexo deve ser separado em tantas partes simples quanto possíveis para possibilitar o entendimento (HOOG, 2017). Na obra intitulada Discurso sobre o Método, publicada em 1637, o filósofo René Descartes, considerado o pai do racionalismo lógico, afirma que os costumes, a história de um povo, e sua tradição cultural influenciam a forma como as pessoas veem e pensam naquilo em que acreditam (ESPINOZA, 2015).

Deste modo, o processo de criação do conhecimento está diretamente relacionado à realidade pela qual o conhecimento é gerado (DESCARTES, 2005). Para Martins (2012, p. 39), o processo de aquisição do conhecimento varia dependendo do entendimento particular dessa realidade. Por isso, antes de se compreender o processo de obtenção do conhecimento, é necessário entender o que é realidade.

\subsection{Ontologia, epistemologia e filosofia}

A ontologia "se refere ao estudo da própria existência, ao último e irredutível ser do qual todos derivam. Nesse sentido, é metafísica. Entretanto, ontologia também significa a determinação daquilo em que se consiste e qual é a essência dos seres, daquilo que existe, portanto, do que é real" (MORA, 2004, p. 2146).

Para compreender a realidade além do mundo físico, na metafísica de Aristóteles, o ser e 0 verdadeiro, no pensamento e nas coisas, tomadas em absoluto, encontram-se as quatro causas das coisas: (i) causa formal ou o lado do ser per si, é a forma ou essência da coisa; (ii) causa material ou do ser em ato, é a matéria da qual consiste a coisa; (iii) causa eficiente ou do ser em potência, refere-se a origem da coisa, ao que tornou possível sua realidade; e, (iv) causa final ou do ser como verdadeiro, é a razão e a finalidade da existência de algo (PEREIRA, 2001; HOOG, 2017).

Ao aplicar analogamente a metafísica no âmbito da Teoria da Contabilidade pode-se inferir, por exemplo, que no estudo do fenômeno do leasing, as causas formais são os negócios realizados pelas partes contratuais; a causa material é o bem objeto da locação; a causa eficiente refere-se à gestão do empreendimento e; a causa final do leasing é a remuneração auferida no negócio.

As questões ontológicas, destinadas à compreensão da realidade, estudadas desde a Grécia antiga, conforme Honderich (1995), Routledge (2000) e Ryan et al. (2002), fundamentam-se nos argumentos do realismo de Platão [O mundo real é o mundo das ideias que contém as formas ideais de tudo (Platão, 427347 a.C)], no relativismo de Protágoras [O homem é a medida de todas as coisas (Protágoras, 490-420 a.C)] e no idealismo de Descartes [Penso logo existo (Descartes, 1596-1650)].

Uma vez compreendida a realidade que permeia os fenômenos, no caso dos fenômenos contábeis, deve-se descobrir como o conhecimento acerca deles é obtido. Esse é o papel da epistemologia. O problema central da epistemologia consiste em decidir como o conhecimento, definido por Platão como crença verdadeira justificada, pode ser obtido (RYAN et al., 2002).

Para Bunge (1980, p. 17), o epistemólogo ligado à ciência e aos mecanismos formais da filosofia contemporânea pode dar importantes contribuições, como trazer à tona os pressupostos filosóficos de planos, métodos ou resultados de investigações científicas da atualidade; elucidar e sistematizar conceitos filosóficos empregados em diversas ciências; participar das discussões sobre a natureza e o valor da ciência pura e aplicada. A epistemologia merece o apoio da sociedade se for útil à ciência e construir o enriquecimento da filosofia, pela reflexão sobre os problemas, métodos, princípios e teorias da ciência.

Considerando que o presente estudo objetiva analisar as bases filosóficas dos princípios contábeis, não é possível obter conhecimento a respeito de um objeto se sua essência não está entendida. A ontologia pode até ser discutida sem a epistemologia, mas a epistemologia é inseparável da ontologia (CROTTY, 1998).

\subsection{Paradigmas, princípios e filosofia}

Para o filósofo Thomas Kuhn, a ciência alterna períodos de normalidade e de crise (BUCKINGHAM et al., 2013). A ciência normal é o processo rotineiro no qual o trabalho desenvolvido pelos pesquisadores dentro de um sistema teórico ou paradigma acumula resultados que não questionam as escolas teóricas desse sistema. Às vezes resultados anômalos aparecem, mas esses são considerados como erros dos cientistas. Contudo, ao longo do tempo tais resultados anômalos vão se acumulando até atingir um ponto de crise. Nesse momento, nova teoria é formulada, há uma mudança no paradigma e um novo sistema teórico substitui o antigo e o ciclo recomeça. 
Kuhn (1996, p. 13) conceitua paradigmas como "conquistas científicas universalmente reconhecidas, que, por um determinado período de tempo municiam problemas, modelos e soluções para uma comunidade de práticos". E as mudanças desses paradigmas acontecem, segundo Kuhn, quando anomalias no padrão vigente estabelecem a crise e arquétipos concorrentes surgem (MACEY, 2000).

Na ciência contábil, Chua (1986) propõe uma visão multiparadigmática para a pesquisa contábil, assim como Tomkins e Groves (1983). Hopper e Powell (1985) afirmam que qualquer pesquisa possui suposições filosóficas e propõe que todo pesquisador deve utilizar aquelas que são consistentes com seus próprios valores e crenças em relação à natureza da sociedade e das ciências sociais (MARTINS, 2012).

Portanto, paradigmas são orientações gerais sobre o mundo e a natureza da pesquisa que representam um conjunto de crenças que guiam ações. Dessa maneira, o paradigma une a ontologia e a epistemologia e cria uma moldura para se criar os passos que serão efetivamente dados na pesquisa. Outra definição refere-se a "um conjunto de crenças científicas e metafísicas que formam uma estrutura teórica dentro da qual as teorias científicas podem ser testadas, avaliadas e, se necessário, revisadas" (AUDY, 1999, p. 641).

Até aqui, o estudo percorreu o caminho que leva ao entendimento sobre o processo de aprendizagem humana para assimilação, no caso da informação contábil; à compreensão da realidade (ontologia) pela qual o conhecimento dos fenômenos (contábeis) é gerado e assimilado como verdade (epistemologia) norteando o comportamento do indivíduo e moldando seu raciocínio lógico. Após estabelecer o conceito de paradigma sob a ótica das crenças que levam o indivíduo a agir tomando por base o conhecimento adquirido e a verdade metafísica das coisas, chega-se ao cerne do presente estudo ao se abordar, doravante, a definição de princípios e sua influência no meio contábil e no comportamento humano.

Como já mencionado, a ciência contábil sustenta-se em princípios, os quais são verdades fundamentais das quais outras decorrem, ou nas quais outras estão baseadas; uma verdade geral; uma proposição básica ou premissa fundamental; uma máxima; um axioma; um postulado. São, portanto, uma lei ou regra geral adotada ou considerada como diretriz de ação; uma base aceita de conduta ou prática (HENDRIKSEN; VAN BREDA, 2009).

Ao analisar as interações entre contabilidade e personalidade, Gambling (1974) propôs, no âmbito do estudo da Teoria Positiva da Contabilidade, um esquema analítico baseado nos estudos da psicanálise de Jung (1939) pelo qual o indivíduo, na qualidade de usuário da informação contábil, molda as informações que Ihe são fornecidas, valendo-se intuitivamente de seu ego como organizador da consciência e de suas percepções. A estrutura psíquica do ser, construída no processo de aprendizagem individual, influencia as interpretações da realidade que lhe são fornecidas.

Segundo Lopes de Sá (2017), o registro contábil era, primordialmente, apenas a expressão da observação de fatos da riqueza, mas, não o próprio fato. Deve-se, portanto, ter consciência de que não basta escriturar, mas, é preciso saber o que fazer com as informações obtidas, ou seja, necessário é entender o que significa, o que aconteceu com a riqueza patrimonial, e o que se evidencia nas demonstrações contábeis. De relativa utilidade é qualquer registro e a demonstração do mesmo, como informação, se não se compreende o que significa, nem se pode tirar conclusões sobre o comportamento do fenômeno registrado. Tal nível de compreensão e interpretação dos fenômenos contábeis devem permear a cultura organizacional, o indivíduo comum e os usuários da contabilidade.

\section{Estabelecimento de Princípios na Ciência Contábil}

Estabelecer princípios na ciência contábil implica identificar os objetivos inerentes ao uso dos conceitos, que podem ser desenvolvidos para identificar algo sobre o qual alguma coisa geral possa ser dita. Generalidades, a priori, são úteis para explicar e prever fenômenos. Um conceito particular, desenvolvido para uma finalidade específica, nada identifica sobre o que pode ser dito de forma generalizada. Assim, no contexto da definição de um padrão, afirma-se que os padrões contábeis baseados em regras têm direcionado a atenção de padronizadores para desenvolverem o tipo errado de padrões (DENNIS, 2008).

De acordo com a Securities and Exchange Commission (SEC, 2003, p. 10), as falhas mais significativas e comumente aceitas dos padrões baseados em regras são precisamente que elas não conseguem atingir os fins desejáveis, que estimulam o desenvolvimento do conceito de um padrão que é baseado em princípios. O conceito de ser baseado em princípios deve ser útil ao direcionar a atenção para outro tipo de padrão que aparentemente atinge os objetivos de maneira mais eficaz. Nessa perspectiva, cabe o questionamento sobre o que deveria ser um padrão baseado em princípios na ciência contábil. Bennett et al. (2006) e Alexander e Jermakowicz (2006) conduzem a uma linha de raciocínio de que os princípios em questão seriam aqueles que levam os contadores e a ciência contábil a permitirem uma visão verdadeira e justa (true and fair view) da contabilidade pelos seus usuários.

Lyas (1993) esclarece que os conceitos são avaliados a partir da perspectiva dos fins da contabilidade. Isso é feito "começando com uma compreensão dos fins que a contabilidade por definição se propõe a alcançar e mostrando que certas atividades particulares dentro da prática contábil não são o meio mais eficiente para esses fins, ou são tais que frustram sua conquista" (LYAS, 1993, p. 157). O ponto chave está em como o uso dessas expressões contribuem para atingir as finalidades e objetivos da contabilidade. 
Nesse arcabouço teórico inserem-se os princípios contábeis. Decorre que um padrão estabelece uma forma de conduta a ser seguida pelos operadores da contabilidade, os princípios subjacentes a essa norma de conduta podem ser considerados consoante duas linhas de raciocínio distintas, porém, complementares e não excludentes. A primeira refere-se à figura dos princípios como regramento, ou seja, o estabelecimento de diretrizes e regras que devem ser adotadas pelo contador no exercício de suas atividades operacionais. A segunda refere-se aos princípios sob uma perspectiva filosófica, voltada aos valores éticos, morais e responsáveis que permeiam o julgamento de valor na conduta do contador. Esse último está relacionado ao pressuposto ontológico da true and fair view.

Ao analisar os princípios contábeis sob a ótica filosófica, convém ressaltar o estudo de Wittgenstein (1953, p. 87), o qual esclarece que "a filosofia não pode de modo algum interferir com o uso real da linguagem; pode, no final, apenas descrevê-la, deixando tudo como está". No entanto, se fornecer razões para os praticantes mudarem a maneira como falam e agem, isso resultará em coisas que não permanecem como estavam. Os filósofos podem relutar em entrar na discussão e em se envolver nessas mudanças, mas as mudanças podem ocorrer como resultado de suas investigações (DENNIS, 2008).

\section{Relevância Italiana na Teoria da Contabilidade}

Coronella e Santaniello (2018), ao analisarem as origens históricas da cultura contábil na Itália, afirmam que Veneza, cidade comercial por excelência, foi o berço de uma série de circunstâncias favoráveis ao desenvolvimento e disseminação da contabilidade, inicialmente entre os mercadores da idade média e renascença, e posteriormente nas empresas e setor público, tendo em vista a necessidade de maior controle sobre o registro e acompanhamento de suas atividades comerciais.

A região do Vêneto, dada sua localização costeira e insular aberta e acessível, segundo Coronella e Santaniello (2018) fomentou rapidamente o desenvolvimento do comércio local e internacional, tendo sido Veneza a primeira cidade italiana a implementar o método de impressão de Gutemberg (1400-1468). Tal fato a tornou responsável pela rápida divulgação e disseminação do método das partidas dobradas nas transações comerciais.

A ascensão da contabilidade moderna é creditada, pelos historiadores e filósofos contábeis, à edição da Summa Arithmetica (1494) do Frei Luca Pacioli, impresso em Veneza, cuja popularização do método das partidas dobradas conferiu ao frade a alcunha de pai da contabilidade (SANGSTER; SCATAGLINIBELGHITAR, 2010). O uso do método das partidas dobradas foi o clímax da contabilidade medieval evoluída nas transações realizadas pelos mercadores e contadores desconhecidos nos séculos XIV e XV (MASI, 1975).

Quanto à paternidade e influência dos registros de dupla entrada ou método das partidas dobradas para a Teoria da Contabilidade, Sargiacomo et al. (2018, p.13) assim expõem:

(...) Fabio Besta afirma que Veneza é a líder (Besta, 1916, p. 349), enquanto Federigo Melis refere-se à Toscana (Melis, 1950, p. 480), mas segundo outras evidências, a origem da dupla entrada foi refeita em Gênova ou Milão (Zerbi, 1952). Entretanto, a dupla entrada é universalmente reconhecida como veneziana desde que referências anteriores a esse estilo já foram citadas em registros mais antigos, que precisaram ser mantidos de acordo com a abordagem veneziana em outras cidades.

Além disso, várias sugestões impulsionam a tese segundo a qual Veneza era a cidade reconhecida como o berço das partidas dobradas. Entre as quatro repúblicas marítimas (Amalfi, Pisa, Gênova e Veneza) que lidavam com comércio e negócios, Veneza era certamente a mais importante, a mais duradoura e a mais ativa das trocas culturais, bem como do comércio com o exterior. Além disso, de volta ao século XV, Veneza era conhecida como uma 'cidade muito rica' - mais especificamente, a mais rica de toda a Península Itálica (Luzzatto, 1960, p. 70). Venice era verdadeiramente a principal cidade comercial do Renascimento. A grandeza dela surgiu de seu vasto império comercial no Oriente e suas vantagens naturais como porto [...]. Ela era o centro ativo do comércio entre o Oriente e o Ocidente e seus lucros eram enormes (Peragallo, 1938, p. 32).

Por esta razão, era natural que Veneza tivesse desenvolvido o famoso método veneziano de dupla entrada. Sua supremacia no comércio é responsável pela disseminação do sistema para outras partes da Itália durante os séculos XIV e XV, e no século XVI, com a ajuda de escritores venezianos e filósofos italianos, por toda a Europa (Peragallo, 1938, p. 32). Foi "o soberano, bem como o moderador do comércio mundial e ostentou as maiores e mais experientes empresas" por um longo tempo, portanto, dando "à [...] contabilidade teórica seus primeiros seguidores" (Alfieri, 1891, p. 1).

Depreende-se que o cenário para o lançamento e impressão dos primeiros trabalhos sobre contabilidade foi preparado por Veneza. De acordo com Peragallo (1938), seja qual for a origem do método das partidas dobradas, Veneza a utilizou, a desenvolveu, a aperfeiçoou e tornou-a sua, e foi sob o nome do método veneziano que se tornou conhecida em todo o mundo (SARGIACOMO et al., 2018). 
De acordo com Bigoni e Funnell (2018) e Coronella e Santaniello (2018), a partir da segunda metade do século XV Veneza assume a liderança do progresso da literatura contábil mundial. Nesse sentido, Sargiacomo et al. (2018, p. 15) destacam:

(...) todos os primeiros tratados mais relevantes sobre escrituração de dupla entrada de Veneza: a Summa por Luca Pacioli (Pacioli, 1494), movendo-se através de obras de Giovanni Antonio Tagliente (1525), Domenico Manzoni (1540), Bartolomeo Fontana (1551) e Alvise Casanova (1558), bem como através de duas obras anônimas (1525 e 1529) e depois para o tratado impresso tardiamente por Benedetto Cotrugli (Cotrugli, 1573). Com exceção do pequeno livreto do matemático e médico Girolamo Cardano, de Milão - cuja obra se limita à manutenção de contas (Cardano, 1539) -, o primeiro trabalho impresso de Veneza data de 1586 e foi lançado por Angelo Pietra (Pietra, 1586).

(...) Os registros de arquivos italianos mais importantes foram - em grande parte disseminados para a comunidade de historiadores da contabilidade através do Livro 9, Volume 3 da publicação histórica de Fabio Besta intitulada La Ragioneria (1916), embora os registros de Andrea Barbarigo tenham sido originalmente mencionados algumas décadas antes, em sua Prolusão a La Ragioneria (1880). Notavelmente, os trechos de Besta (1916) foram referidos por comentaristas e pesquisadores internacionais muito influentes, como Littleton (1928, 1933), Katz (1930), Peragallo (1938, 1956) e de Roover (1944, 1954, 1956) (Sargiacomo, Servalli e Andrei, 2012; Andrei, Baker e Sargiacomo, 2017).

Pacioli encerrou o período da contabilidade da Idade Média e abriu o caminho da contabilidade renascentista e moderna. Durante o Século XVI "os tratados venezianos ainda predominam na Itália e em todo mundo (...) demonstrando sem dúvida a liderança cultural absoluta de Veneza em relação à dupla entrada" (CORONELLA; SANTANIELLO, 2018, p. 32). No tocante ao destaque de Veneza na difusão e progresso da literatura contábil mundial Coronella e Santaniello $(2018$, p. 48$)$ afirmam que:

(...) o primeiro trabalho sobre o método veneziano emitido fora da Itália remonta a 1543 por Jan Ympyn Christofells, um comerciante de Anversa que permaneceu por mais de doze anos em Veneza, onde aprendeu os detalhes do método. (...) O primeiro tratado inglês remonta a 1543, e foi escrito por um professor de Londres, Hugh Oldcastle. Entretanto, de acordo com estudiosos (Brown, 1905, 127), seu trabalho é de fato a versão traduzida em inglês do Tractatus de computis et scripturis de Luca Pacioli. (...) Na Alemanha, o sistema de partidas dobradas foi introduzido por Wolffgung Schweicker. Ele morou em Veneza para se familiarizar com o método italiano e, em 1549, lançou seu tratado contábil, valendo-se consideravelmente do trabalho de Manzoni (Vlaemminck, 1956, 107-111; Chatfield, Vangermeersch, 1996, 520).

$\mathrm{Na}$ França, ainda sem influências do movimento iluminista, que só viria a surgir em meados do século XVII e início do século XVIII (o século da filosofia), o método das partidas dobradas foi descrito, primeiramente, por Pierre de Savonne em sua obra de 1567; o segundo autor francês do século XVI é Martin Fustel, cujo trabalho é dedicado principalmente à aritmética aplicada (BIGONI; FUNNELL, 2018). Entretanto, os filósofos e pesquisadores europeus do século das luzes proporcionaram importantes contribuições para a evolução do pensamento científico, pois seus estudos acerca da essência do conhecimento possibilitaram o fortalecimento de princípios e da true and fair view na Teoria da Contabilidade.

\section{Princípios Contábeis Brasileiros e Franceses}

A Contabilidade é fortemente influenciada pelo ambiente em que atua pelo fato de ser uma ciência social. Assim, diferenças históricas, valores culturais e estruturas políticas, legais e econômicas de cada país acabam refletindo nas práticas contábeis. Por conseguinte, os princípios e as práticas contábeis podem variar de um país para outro. Em alguns países, como é o caso do Brasil, a Contabilidade é influenciada pela exigência legal; em outros, pelo consenso de órgãos profissionais de classe, como é o caso dos Estados Unidos (NIYAMA; SILVA, 2013). À luz desses fatores, os princípios contábeis, os padrões e os normativos reguladores da profissão contábil locais variam entre os países.

Os princípios funcionam como parte estrutural do sistema contábil, na aplicação de regras para a escrituração e elaboração de relatos e demonstrativos. Representam, portanto, todo um conjunto de preceitos normativos ou convencionais, que regem os registros dos fatos e dados das relações patrimoniais pela contabilidade enquanto ciência ou política. Hoog (2017) evidencia que a ciência contábil possui princípios científicos que são libertos de fronteiras universais, e autônomos por constituírem a própria doutrina da contabilidade, diferentemente da política contábil que age pela via da promulgação de normas.

Princípios contábeis legalmente instituídos ou academicamente constituídos no Brasil e na França são elucidados, de forma a possibilitar a análise dos preceitos filosóficos subjacentes. A vigência ou não da norma que instituiu os princípios elencados não se constitui em dado relevante, uma vez que o foco da análise é o reflexo da história, dos valores, da cultura e dos costumes do povo em seus regramentos, e não o instituto legal per si. 
Dessa forma, os trabalhos científicos de Finney e Miller (1963) e Nobes e Parker (2010), assim como do AICPA (1975), possibilitam o entendimento e compreensão acerca dos princípios universais da contabilidade. No Brasil, o estudo de Hoog (2017) evidencia os princípios elencados no Quadro 1.

\begin{tabular}{|c|c|}
\hline Princípios contábeis & Descrições sucintas \\
\hline Coexistência & $\begin{array}{l}\text { Princípio segundo o qual, uma conta depende sempre da existência de outra, } \\
\text { ou seja, existem sempre simultaneamente. }\end{array}$ \\
\hline Competência & $\begin{array}{l}\text { As receitas e despesas devem ser incluídas na apuração do resultado do } \\
\text { período em que ocorrerem, sempre simultaneamente quando se } \\
\text { correlacionarem, independentemente de recebimento ou pagamento. }\end{array}$ \\
\hline Consistência & $\begin{array}{l}\text { Princípio segundo o qual é possível a comparação de dados por uniformidade } \\
\text { das informações. }\end{array}$ \\
\hline Continuidade & $\begin{array}{l}\text { A continuidade ou não da entidade, bem como sua vida definida ou provável, } \\
\text { deve ser considerada quando da classificação e avaliação. }\end{array}$ \\
\hline Correção Monetária & $\begin{array}{l}\text { Princípio segundo o qual se ajustam os valores patrimoniais de acordo com a } \\
\text { perda do poder aquisitivo da moeda. }\end{array}$ \\
\hline Custo Histórico & $\begin{array}{l}\text { Regra segundo a qual se efetuam as comparações dos investimentos, custos e } \\
\text { despesas com as previsões tidas como ideais. }\end{array}$ \\
\hline Entidade & $\begin{array}{l}\text { Lei geral relativa à autonomia patrimonial, segundo a qual, a pessoa de um } \\
\text { sócio não se confunde com a pessoa jurídica, pois ambas têm autonomia } \\
\text { patrimonial. }\end{array}$ \\
\hline Equidade & $\begin{array}{l}\text { Princípio segundo o qual devem ser afastados os conflitos de interesse nos } \\
\text { registros contábeis pela preservação de critérios de igualdade e moderação. }\end{array}$ \\
\hline Imprevisibilidade & $\begin{array}{l}\text { A imprevisibilidade está notoriamente ligada a eventos subsequentes à data de } \\
\text { registro de uma previsão contábil. As estimativas introduzem um elemento de } \\
\text { imprevisibilidade ou aleatoriedade na atividade empresarial. Portanto, quanto } \\
\text { maior for a precisão, maior a probabilidade de acerto. }\end{array}$ \\
\hline Expressão Monetária & $\begin{array}{l}\text { Princípio pelo qual todos os componentes patrimoniais têm uma medida e } \\
\text { registro do seu valor monetário. }\end{array}$ \\
\hline Extensão & $\begin{array}{l}\text { Princípio segundo o qual a extensão das contas deve atender às necessidades } \\
\text { totais da escrituração contábil. }\end{array}$ \\
\hline Formalização & $\begin{array}{l}\text { Estabelece que todos os fatos contábeis devem ser caracterizados na escrita } \\
\text { contábil }\end{array}$ \\
\hline Homogeneidade & $\begin{array}{l}\text { Princípio segundo o qual uma conta só pode registrar fatos de uma mesma } \\
\text { natureza. }\end{array}$ \\
\hline Integração & $\begin{array}{l}\text { Princípio segundo o qual os balanços devem ser consolidados ou integrados } \\
\text { quando pertencem a um mesmo grupo econômico. }\end{array}$ \\
\hline Integridade & $\begin{array}{l}\text { Enuncia que todos os fatos contábeis que digam respeito à mesma natureza } \\
\text { sejam unidos em uma única conta contábil. }\end{array}$ \\
\hline Invariabilidade & $\begin{array}{l}\text { Princípio segundo o qual as contas devem ser previamente estabelecidas, } \\
\text { mantendo, durante todo o exercício social, a uniformidade dos títulos, funções } \\
\text { e técnicas de funcionamento. }\end{array}$ \\
\hline Materialidade & $\begin{array}{l}\text { Princípio que enuncia a conveniência ou não de incluir um dado ou informação } \\
\text { nas peças contábeis, em razão da importância ou relevância que possa ter para } \\
\text { os usuários. }\end{array}$ \\
\hline Oportunidade & $\begin{array}{l}\text { Refere-se simultaneamente à tempestividade e à integridade do registro do } \\
\text { patrimônio e suas mutações, determinando que este seja feito de imediato e } \\
\text { com a extensão correta, independentemente das causas que as originaram. }\end{array}$ \\
\hline Periodicidade & Determina o mesmo período de duração e apuração do rédito. \\
\hline Prudência & $\begin{array}{l}\text { Determina a adoção do menor valor para os componentes do Ativo e do maior } \\
\text { valor, para os do Passivo, sempre que se apresentarem alternativas igualmente } \\
\text { válidas para a quantificação das mutações patrimoniais que alterem o } \\
\text { patrimônio líquido. }\end{array}$ \\
\hline Qualificação-Quantificação & $\begin{array}{l}\text { Princípio que enuncia a obrigação da expressão qualitativa e quantitativa da } \\
\text { riqueza. }\end{array}$ \\
\hline Uniformidade Contábil & $\begin{array}{l}\text { Determina a manutenção de critérios sempre iguais na execução do labor } \\
\text { contábil e objetiva evitar distorções nos fatos patrimoniais. }\end{array}$ \\
\hline Terminologia Contábil & $\begin{array}{l}\text { Estabelece a necessidade do uso de categorias e vocábulos adequados à } \\
\text { perfeita realização da contabilidade. A linguagem deve ser sempre a científica } \\
\text { e não a coloquial, preservando-se o idioma nacional, a clareza e a fidelidade. }\end{array}$ \\
\hline
\end{tabular}

Fonte: Elaboração própria.

No Brasil, em 23 de outubro de 1981 o Conselho Federal de Contabilidade (CFC) editou a Resolução nํ 530, que aprovou 16 princípios fundamentais de contabilidade, alegando explicitamente que até aquela data inexistia no país um consenso sobre os mesmos. A Resolução definia como princípios os conceitos e postulados gerais emanados da doutrina contábil, voltados ao tratamento contábil uniforme dos atos e fatos administrativos e das demonstrações deles decorrentes. 
Ao considerar que a evolução da ciência contábil em uma década reclamava a atualização substantiva e adjetiva dos princípios fundamentais de contabilidade, o CFC revogou a referida norma pela Resolução no 750, de 29 de dezembro de 1993. À época, foram reduzidos a apenas sete princípios contábeis: Entidade, Continuidade, Oportunidade, Registro pelo Valor Original, Atualização Monetária, Competência e Prudência. No entanto, havia a premissa subjacente de que na aplicação dos princípios à situações concretas deve prevalecer a essência das transações sobre seus aspectos formais.

Os normativos vigentes desde a década de 1980 continham a ideia de que os princípios de contabilidade representavam a essência das doutrinas e teorias relativas à Ciência Contábil. Tal fato, por refletir o entendimento predominante nos universos científico e profissional no país, conferia à Contabilidade o seu sentido mais amplo de ciência social, cujo objeto é o patrimônio das entidades.

No regramento normativo contábil brasileiro atual, no entanto, inexiste a evidenciação expressa dos princípios contábeis, uma vez que a estrutura conceitual vigente a partir de 1 o de janeiro de 2017 revogou a Resolução CFC no 750/1993, sem, no entanto, deixar de considerar em seu escopo, porém de forma implícita, os princípios e pressupostos norteadores de conduta dos contadores para o exercício profissional.

$\mathrm{Na}$ França, o estudo de Richard e Collete (2005) relata os princípios da contabilidade comumente adotados, conforme evidenciado no Quadro 2.

\section{Quadro 2: Princípios contábeis na França}

\section{Princípios contábeis}

Neutralité/Subjectivité

(Neutralidade/subjetivida de)

\section{Entité/Unicité}

(Entidade / Unicidade)

Comptabilité de caisse / d'engagements

/ compromissos)
(Compatibilidade de caixa

Para ser confiável, as informações contidas nas demonstrações financeiras devem ser neutras, isto é, sem viés. As demonstrações contábeis não são neutras se, por meio da solução ou apresentação de informações, elas influenciam a tomada de decisão ou julgamento a fim de alcançar um resultado ou resultado predeterminado.

A criação e o desenvolvimento de uma entidade ou empresa pressupõem que os fundadores ou fornecedores de fundos subsequentes aloquem uma parte da sua riqueza pessoal a essa entidade. A questão tem sido que ao estabelecer o balanço da entidade empresarial em causa, deve-se: considerar apenas os ativos que são atribuídos à entidade, de acordo com o princípio da entidade; ou, ao contrário, agrupar todos os bens do proprietário da empresa (afetivos ou pessoais) de acordo com o princípio da unicidade do patrimônio.

A contabilidade de caixa registra somente recebimentos e desembolsos. Nesse tipo de contabilidade, o ativo é representado pelo caixa e passivo existentes pelo capital monetário correspondente; o resultado de um período corresponde às alterações no capital monetário, ou seja, a diferença entre entradas de caixa e desembolsos durante o período considerado.

As contas de acréscimo (ou despesa e receita) levam em conta não só o caixa, mas também os recebíveis e outros ativos ilíquidos (compromissos positivos) e incluem no passivo não apenas capital monetário, mas também dívidas (compromissos negativos). Dadas essas escolhas, elas são levadas a mensurar o resultado em termos de despesas e receitas.

Propriété / prééminence de la substance

(Propriedade preeminência

As contas estáticas, que são projetadas para mensurar a solvência, são geralmente baseadas no princípio de propriedade, pelo qual os ativos podem ser reconhecidos apenas como propriedades. Pelo contrário, a contabilidade do tipo dinâmico é substância) geralmente regida pelo princípio da predominância da substância pela forma, segundo a qual, em princípio, todos os bens utilizados, sejam ou não objeto de um direito de propriedade, são inscritos para o ativo.

Séparation / unicité des périodes

(Separação / unicidade de períodos)

Coûts / valeurs

(Custos / valores)

Em certas contas, a mensuração do resultado dos investimentos realizados é concebida apenas numa base aperiódica, tendo em conta todos os resultados obtidos ao longo de todo o período de investimento considerado: é, na maior parte, caixa e contabilidade atuarial, ou seja, dois tipos de contabilidade com base no monitoramento dos fluxos de caixa globais gerados por um investimento. Nestes tipos de contabilidade, o princípio da unicidade do período é usado para determinar o resultado.

Desde praticamente o início da revolução industrial, um conflito coloca os partidários das contas em custos de valor (custos) para os partidários das contas em valores de preço (valores); este conflito corresponde em parte àquele que se opõe em economia ao partidarismo das teorias clássicas e marxistas aos partidários das teorias neoclássicas.

$\begin{aligned} & \text { Rattachement / non- } \\ & \text { rattachement } \\ & \text { (Reconexão / não } \\ & \text { fixação) }\end{aligned}$
$\begin{aligned} & \text { Prudences / imprudence } \\ & \text { (Prudência / imprudência) }\end{aligned}$

A contabilidade do tipo dinâmica baseia-se no princípio de que as despesas (custos) estão relacionadas às receitas, ou seja, elas mensuram os ativos não disponíveis à venda pelo seu custo e alocam esse custo a qualquer período de utilização dos ativos em causa, independentemente das flutuações do seu valor.

O princípio da precaução/prudência está estabelecido no Código Comercial francês: as contas anuais devem respeitar o princípio da precaução (CC14), ou seja, a contabilidade é estabelecida com base em avaliações cautelosas para evitar o risco de transferir, para períodos futuros, as incertezas presentes que provavelmente sobrecarregam a propriedade e o resultado da entidade. Consiste em registrar as perdas potenciais e não levar em conta os lucros potenciais. 
Princípios contábeis

Coût historique / coût réévalue

(Custo histórico / custo reavaliado)

Continuité/mort

(Continuidade / morte)

Descrições sucintas

O problema da reavaliação é similar ao da estimativa de valor de mercado ou do valor atuarial. Isso pode ocorrer também no caso da contabilização de custos, como no caso de contabilidade de valor atuarial ou de mercado: portanto, não se pode confundir reavaliação com estimativa.

As demonstrações financeiras são normalmente preparadas no pressuposto de que uma empresa está em funcionamento e continuará a operar no futuro previsível. Assim, supõe-se que a empresa não tem a intenção nem a necessidade de encerrar suas atividades, nem de reduzir significativamente o tamanho de suas atividades. Se houver tal intenção ou necessidade, as demonstrações contábeis podem precisar ser preparadas em uma base diferente e, em caso afirmativo, a base usada deve ser indicada.

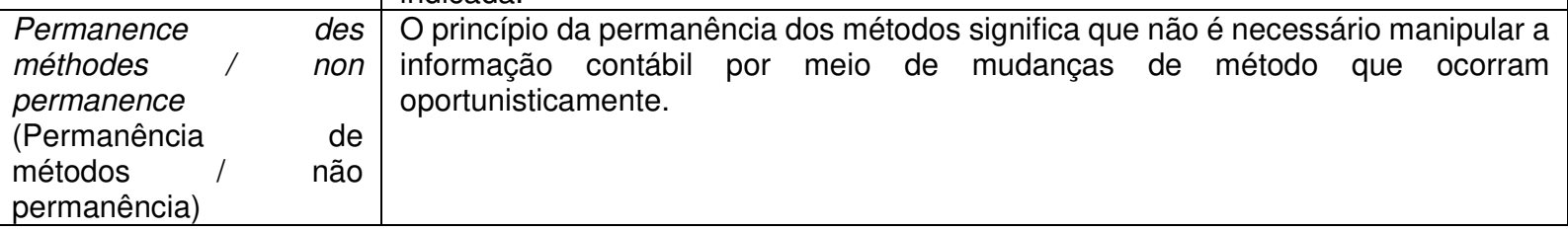

Fonte: Elaboração própria.

Os princípios iluministas de Liberdade, Igualdade e Fraternidade, que foram o lema da Revolução Francesa no século XVIII, exerceram tamanha influência na cultura e nos costumes dos franceses que se encontram citados nas duas últimas Constituições Francesas de 1946 e 1958. Porém seus preceitos extrapolam os ideais sociodemocráticos revolucionários de outrora, uma vez que até os dias atuais o lema de igualdade parece nortear, no âmbito da Ciência Contábil Francesa, a premissa da L'image Fidèle (imagem fiel e igualitária).

A congruência de pressupostos e afinidade de propósitos entre a 'imagem fiel e igualitária' e a 'visão justa e verdadeira', pode ser constatada nos estudos de Rutherford (1985), cujo conceito da True and fair View compreende tanto a honestidade da representação como o "reconhecimento da essência econômica acima da mera forma legal" (PARKER; NOBES, 1991, p. 359).

Em meados do século XX, países como a França e a Alemanha, na condição de membros da União Europeia, somente aceitaram incorporar o conceito da True and Fair View na Quarta Diretiva Europeia, uma vez que sua filosofia serviria para a boa causa da imagem fiel (L'image Fidèle) dos registros contábeis (RICHARD; COLLETE, 2005).

Depreende-se do exposto que vários dos princípios elencados, tanto no Brasil como na França, possuem características operacionais, isto é, que denotam mais o modus operandi dos registros contábeis do que ideais filosóficos de comportamento social. Tal fato consiste em um paradoxo, visto que se trata de características concernentes aos países cuja estrutura conceitual é baseada em regras, e não em países cujas estruturas são baseadas em princípios como é o caso do Brasil e da França.

\section{Fundamentos Filosóficos Subjacentes}

O valor da filosofia para a ciência contábil pode ser atribuído à importância argumentativa e crítica necessária para se fundamentar os conceitos das coisas que, por sua vez, envolvem a descoberta da verdade real (HOOG, 2017). Nesse ínterim, o processo epistemológico da criação do conhecimento contábil envolve o debate, o processo dedutivo, as argumentações e o crivo da lógica como requisito de validade de um princípio, uma teoria, de uma conclusão, ou de uma conduta.

A filosofia da igualdade francesa encontra respaldo na literatura brasileira, pelos ensinamentos do jurista Rui Barbosa (2003, p. 19) em seu discurso de oração aos moços, em que afirmava que "a regra da igualdade não consiste senão em quinhoar desigualmente aos desiguais, na medida em que se desigualam. Nesta desigualdade social, proporcionada à desigualdade natural, é que se acha a verdadeira lei da igualdade". Consiste, portanto, de tratar os iguais como iguais e os desiguais como desiguais.

Esta assertiva se aplica à contabilidade na medida em que as normas, regulamentos e padrões estabelecidos pelas estruturas conceituais, aliados ao processo de globalização e convergência às normas internacionais de contabilidade, objetivam harmonizar conceitos, padronizar formas de apresentação e procedimentos. Assim, o conhecimento dos preparadores dos relatos financeiros vai além dos limites da comparabilidade almejada em um processo de harmonização contábil; ele perpassa o entendimento do ser, da conduta alheia e das histórias e costumes inerentes à região geográfica onde se pratica determinado procedimento contábil.

A filosofia tem como um de seus propósitos o estudo do conhecimento. Neste sentido discorre-se sobre estudos desenvolvidos por alguns dos principais filósofos que contribuíram às ciências sociais no processo de construção da sabedoria humana, os quais se aplicam à contabilidade. Sócrates (469-399 a.C), filósofo grego, tratou da ética como ramo da filosofia voltado ao estudo dos valores, princípios e ideais do homem. Questionava a natureza e o caráter dos homens e suas implicações éticas e sociais. Dentre seus 
ensinamentos sobre a ética tem-se: o conhecimento como virtude; a educação como forma de autoconhecimento; e a obediência às leis e normas como garantidoras da ordem social e da vida em sociedade.

Os princípios socráticos são aplicáveis à ciência contábil na medida em que os órgãos reguladores e entidades de classe buscam padrões normativos e estruturas conceituais enquanto forma de aprimoramento dos princípios fundamentais da contabilidade, como premissas, postulados, leis ou regramento geral, adotados pelo público alvo como base aceita de norma de conduta ou prática. Aplicam-se, portanto, aos princípios da Terminologia contábil, da Consistência, da Formalização, da Expressão Monetária, da Uniformidade Contábil e da Comptabilité de caísse/d'engagements francesa.

Para Aristóteles (384-322 a.C), a ética é fruto da prática constante de atos virtuosos que criam hábitos mantenedores do bem estar social. Dedicou-se ao estudo da moral. Isso pode ter motivado uma das definições atuais de ética: "a área da filosofia que se ocupa do estudo das normas morais da sociedade" (CHAUI, 2014, p. 385). Vincula-se, portanto, aos costumes. Afirmava, ainda, que a ética tem por objetivo precípuo a conquista da felicidade, como forma de se alcançar o bem estar social.

O pensamento aristotélico aplica-se, portanto, ao pressuposto ontológico da true and fair view, visão justa e verdadeira, em que a consciência e os valores morais norteiam o senso de julgamento e conduta do contador. De acordo com Lopes de Sá (1996, p. 27), "agir, pois, de acordo com uma consciência moldada em defeitos, pode ser normal para o defeituoso, mas não o será perante o julgamento geral de terceiros". Dessa forma, a virtude deve ser praticada e cultuada com frequência, objetivando o bem comum e o decoro profissional.

Pode-se considerar que os padrões éticos e morais de conduta, ainda que pertinentes ao exercício da profissão contábil e à quase totalidade de seus princípios, são especialmente aplicáveis e oportunos aos princípios brasileiros da Entidade, Materialidade e Oportunidade, assim como aos da Neutralité / Subjectivité, Entité / Unicité, e Permanence des méthodes / non permanence franceses.

Pitágoras (570-495 a.C), filósofo grego e matemático, afirmava que o número era o regente de todas as formas e ideias. Ao desenvolver sua teoria do cálculo aritmético e da geometria, se referia aos números como marcos, a medição dos campos, a demonstração de algo que o homem vê da mente, em uma alusão ao raciocínio lógico, posteriormente estudado por Aristóteles.

A epistemologia pitagórica e seus estudos de medição aplicam-se aos princípios contábeis brasileiros do Custo Histórico, da Expressão Monetária e da Qualificação-Quantificação, e aos princípios de Coûts / Valeurs e Coût historique / Coût réévalue franceses. Tanto o raciocínio ético aristotélico, quanto a medição pragmática de Pitágoras podem se aplicar à premissa da imagem fiel e igualitária francesa (L’image Fidéle).

A filosofia, no entanto, não se restringia à Grécia antiga e à Europa ocidental. Em época contemporânea aos filósofos gregos clássicos, na China, Confúcio (551-479 a.C) preconizava a fidelidade e a sinceridade como princípios básicos do ser humano. Na lógica de Confúcio, a fidelidade e sinceridade são qualidades que dão visibilidade à virtude. Dessa forma, como o exercício da virtude pode ser visto pelos outros, as pessoas são então transformadas pela virtude, o que confere à lealdade e fidelidade o poder de transformação.

A regra de ouro de Confúcio pressupõe que a reciprocidade deve governar as ações do indivíduo em relação aos outros. Advêm desta regra as assertivas, "faça como desejaria que fizessem a você" ou "o que você não deseja para si mesmo não faça aos outros" (BUCKINGHAM et al., 2013, p. 39). Assim, as relações virtuosas moldam o caráter do homem, segundo o conceito de persona de Jung, no processo de aprendizagem do ser.

Os princípios da fidelidade e da sinceridade entre as relações humanas deslocam o então pensamento teocêntrico dominante na antiguidade para o homem (fundamentos do iluminismo) (RICHARD; COLLETTE, 2005; CHAUI, 2014). Por esta razão a filosofia iluminista de ruptura religiosa ao teocentrismo norteou a revolução francesa sobre o lema lgualdade, Liberdade e Fraternidade, conferindo ao ser humano, o poder sobre seu próprio destino (CHAUI, 2014; CASTILHO, 2018).

A sinceridade confuciana está diretamente relacionada à verdade socrática e aristotélica, em que 0 bem se encontra indissociavelmente ligado à verdade real e sua representação. Tal fundamento encontra-se ligado às características qualitativas universais da informação contábil de relevância e representação fidedigna. De igual forma, para a compreensão da realidade e fidelidade, aplica-se o pensamento de Confúcio aos princípios contábeis brasileiros da Extensão e da Homogeneidade, e aos de Séparation / Unicité dés périodes francês, e às relações humanas que permeiam a profissão contábil.

$\mathrm{Na}$ idade média, São Tomás de Aquino colocou a razão ao nível da fé. Para tanto, deu nova interpretação ao pensamento de Aristóteles sobre o estudo da lógica e da ética. Castilho (2018) afirma que para São Tomás de Aquino há três categorias de leis: a lei eterna, como razão da sabedoria divina direcionando os atos e práticas dos seres; a lei natural, que se refere à atividade moral do homem; e a lei positiva humana, que são normas e regras que devem ser sempre orientadas para a rejeição do mal e a busca da virtude. Resulta, portanto, da inteligência humana e sua vontade, tendo como princípio a sindérese, que conforme Hoog (2017) representa um aglomerado de princípios norteadores da conduta humana para a prática do bem e a evitar o mal.

Oficializado pela igreja católica como o pai da filosofia da moderação, Tomás de Aquino afirmava que 
"justiça é dar a cada um de acordo com o seu merecimento" (CASTILHO, 2018, p. 67). Seus ensinamentos coadunam-se aos princípios da Equidade, Uniformidade Contábil e Integridade.

Voltaire (1694-1778), filósofo iluminista francês, afirmava que o mal, em sua concepção e na qualidade de agente distorcivo da verdade, não se tratava de uma abstração metafísica, e sim de um fato social cuja correção dependia exclusivamente da educação, do trabalho e da razão. Defendia a liberdade de expressão como meio de alcance da felicidade humana. No entanto, no tocante aos significados e à forma de assimilação da informação detinha uma especial preocupação com a justiça. "Aqueles que fazem você acreditar em besteiras podem fazer você cometer atrocidades" (VOLTAIRE, 1829, p. 30; CASTILHO, 2018, p. 100).

Aplica-se, portanto, ao princípio da L'image Fidèlle e ao pressuposto da essência sobre a forma à medida que defende a liberdade e eleva o processo de aprendizagem humana ao status de meio para assimilação da verdade, e disseminação do conhecimento puro pela fraternidade para o bem estar social. Os ideais de Voltaire corroboram ainda a filosofia da visão justa e verdadeira das ciências sociais (True and fair view) e ao princípio contábil francês da prééminence de La substance.

René Descartes (1596-1650) desenvolveu um método que pressupõe a simplificação no processo de aprendizagem. Dessa forma, a separação em partes simples de tudo o que parece ser complexo para possibilitar o entendimento, configura um caráter operacional ao registro das informações contábeis à sua respectiva interpretação pelos usuários. Assim, princípios contábeis operacionais, como o da Competência, Continuidade, Periodicidade, Integração, Invariabilidade, Uniformidade Contábil, Séparation/Unicité dês périodes, Continuité e Rattachement/non-rattachement, podem ser atribuídos à filosofia cartesiana de método e aprendizagem.

Isto posto, argumenta-se que os fundamentos filosóficos que possivelmente tenham norteado a concepção dos princípios em análise, podem contribuir para o debate acadêmico quanto ao entendimento dos padrões de comportamento observados na ciência contábil pelos seus operadores de fato e de direito

\section{Considerações Finais}

Pela análise dos embasamentos filosóficos que norteiam os princípios contábeis, observa-se que no processo de construção e consolidação do conhecimento na contabilidade pelos ramos da ontologia e axiologia da ciência, o estudo dos princípios, valores, e regramentos delineadores da profissão contábil, de seus operadores e usuários, perpassam indiscutivelmente pela filosofia.

A liberdade e a igualdade, no âmbito das ciências sociais, surgem em decorrência de leis sociológicas. Sob uma ótica evolutiva, a assimetria de informação diminui quando se uniformiza o nível de consciência e cresce a adaptação social. São duas perspectivas, a da pressão e a da estrutura, sendo que a última decorre da primeira. Assim se percebe como a igualdade e a liberdade se complementam. O exercício de poder, por parte de um ou de todos promove a desigualdade e reflete, por conseguinte, sua influência nas ciências sociais.

Especula-se que seja esse o desafio do processo de convergência contábil no contexto globalizado: as relações de poder sobre a contabilidade. No estudo demonstrou-se que os princípios contábeis, em sua concepção, convergem e se alinham aos pressupostos filosóficos da ética, da moral e da busca pela verdade. As estruturas conceituais e os normativos brasileiros e franceses vigentes têm pautado a confecção dos relatos financeiros nos princípios ontológicos da essência sobre a forma, da L'image Fidélle, e da true and fair view, independentemente dos costumes locais e padrões de comportamento diferenciados.

Observa-se pelo exposto neste estudo que está assegurada a manutenção das raízes italianas filosóficas enquanto berço da contabilidade, concernentes à busca da verdade e garantia da veracidade dos registros contábeis aristotélicos de Luca Pacioli (1445-1517), cujo método veneziano foi precursor de uma escrituração cartesiana, posteriormente lapidada em sua essência pelo movimento iluminista.

Por outro lado, uma vez que de acordo com o empirismo preconizado por Francis Bacon (1561-1626) toda forma de conhecimento importa em relações de poder, propõe-se como agenda futura, a análise do disclosure das informações contábeis do século XXI, à luz do processo de convergência internacional, sob a ótica dos fundamentos filosóficos da verdade, da ética e da moral, e, das relações de poder entre os atores envolvidos.

\section{Referências}

ALEXANDER, David J. A.; JERMAKOWICZ, Eva K. A true and fair view of the principles/rule debate. Abacus, v. 42, n. 2, p. 132-164, 2006. DOI: https://doi.org/10.1111/j.1467-6281.2006.00195.x

AMERICAN INSTITUTE OF CERTIFIED PUBLIC ACCOUNTANTS (AICPA). INTERNATIONAL PRACTICE EXECUTIVE COMMITTEE. Professional Accounting in $\mathbf{3 0}$ Countries. (OCoLC)777345135. New York: The Committee, 1975.

AUDY, Robert. The Cambridge dictionary of Philosophy. 2. ed. Cambridge: Cambridge University Press, 
1999.

BARBOSA, Rui. Oração aos moços. São Paulo: Martin Claret, 2003.

BENNETT, Bruce; BRADBURRY, Michael; PRANGNELL, Helen. Rules, principles and judgments in accounting standards. Abacus, v. 42, n. 2, p. 189-204, 2006. DOI: https://doi.org/10.1111/j.14676281.2006.00197.x

BIGONI, Michele; FUNNELL, Warwick. The Italian and Iberian influence in Accounting History: The imperative of power. London: Routledge, 2018.

BUCKINGHAM, Will; BURNHAM, Douglas; KING, Peter J.; HILL, Clive; WEEKS, Marcus; MARENBON, John. The philosophy book. London: Dorling Kindersley, 2013.

BUNGE, Mario. Epistemologia: Curso de atualização. Tradução de Caludio Navarra. São Paulo: T.A. Queiroz/ EdUSP, 1980.

BYRNE, Gilbert R. To what extent can the practice of accounting be reduced to rules and Standards? In: COUCHMAN, Charles B. (Leader). A Round Table. New York, 1937. pp. 364-379.

CASTILHO, Ricardo. Filosofia geral e jurídica. 5. ed. São Paulo: Saraiva, 2018.

CHAUI, Marilena. Convite à filosofia. 14. ed. São Paulo: Ática, 2014.

CONSELHO FEDERAL DE CONTABILIDADE (CFC). Resolução CFC $\mathbf{n} \times \mathbf{5 3 0}, 23$ de outubro de 1981. Aprova Princípios Fundamentais de Contabilidade. DOU de 26/01/1982 (no 17, Seção I, pág. 1.568).

CONSELHO FEDERAL DE CONTABILIDADE (CFC). Resolução CFC no 750, de 29 de dezembro de 1993. Dispõe sobre os Princípios Fundamentais de Contabilidade. DOU de 31/12/1993 (nº 250, Seção I, pág. 21.582).

CORONELLA, Stefano; SANTANIELLO, Lucrezia. The Venetian Treatises: A Frame. In: SARGIACOMO, Massimo; CORONELLA, Stefano; MIO, Chiara; SOSTERO, Ugo; DI PIETRA, Roberto (Eds.). The origins of accounting culture: The Venetian Connection. London: Routledge, 2018. pp. 31-59.

CROTTY, Michael. The foundation of social research: Meaning and perspectives in the research process. Crows Nest: Sage Publications Ltd., 1998.

CHUA, Wai Fong. Radical developments in accounting thought. The Accounting Review, v. 61. n. 4, p. $601-$ 632, 1986.

DESCARTES, René. Discurso do método. Tradução de Paulo Neves. Porto Alegre: Coleção L\&PM Pocket, 2005.

DENNIS, lan, A conceptual enquiry into the concept of a 'principles-based'accounting standard. The British Accounting Review, v. 40, n. 3, p. 260-271, 2008. DOI: https://doi.org/10.1016/j.bar.2008.05.005

DURANT, Will. A História da Filosofia. 2. ed. Trad. Luiz Carlos do Nascimento Silva. Rio de Janeiro: Nova Cultural, 1996.

EASTERBY-SMITH, Mark; THORPE, Richard; JACKSON, Paul. Management research. Londres: Sage, 1991.

ESPINOZA, Benedictus de. Princípios da filosofia cartesiana e pensamentos metafísicos. Tradução Homero Santiago e Luís César Guimarães Oliva. Belo Horizonte: Autêntica Editora, 2015.

FINANCIAL ACCOUNTING STANDARDS BOARD (FASB). Proposal principles-based aproach to U.S. standing setting. FASB, Connecticut, 2002.

FINANCIAL ACCOUNTING STANDARDS BOARD (FASB) / INTERNATIONAL ACCOUNTING STANDARDS BOARD (IASB). Preliminary views Conceptual Framework for Financial Reporting: Objective of Financial Reporting and qualitative characteristics of decision-useful Financial Reporting Information. FASB, Connecticut, 2006. 
FINNEY, Henry A.; MILLER, Herbert E. Principles of Accounting: Introductory. 6th ed. Englewood Cliffs, New Jersey: Prentice-Hall, Inc., 1963.

GAMBLING, Trevor. Positive accounting: Problems and solutions. London: Macmillan Press, 1974.

HONDERICH, Ted. The Oxford companion to philosophy. Nova lorque: Oxford University, 1995.

HOOG, Wilson Alberto Zappa. Filosofia aplicada à contabilidade. 3. ed. Curitiba: Juruá, 2017.

HOPPER, Trevor; POWELL, Andrew. Making sense of research into the organizational and social aspects of management accounting: A review of its underlying assumptions. Journal of Managment Studies, v. 22, n. 5, p. 429-465, 1985. DOI: https://doi.org/10.1111/j.1467-6486.1985.tb00007.x

INTERNATIONAL ACCOUNTING STANDARDS BOARD (IASB). Framework for the preparation and presentation of financial statements. 2010. Disponível em: http://www.ifrs.org. Acesso em: 23 jul. 2018.

IUDíCIBUS, Sérgio de. Teoria da contabilidade. 10. ed. São Paulo: Atlas, 2010.

IUDÍCIBUS, Sérgio de; MARTINS, Eric Aversari. Estudando e pesquisando Teoria: O futuro chegou? Revista Universo Contábil, v. 11, n. 1, p. 06-24, 2015. DOI: https://doi.org/10.4270/ruc.2015101

JUNG, Carl Gustav. Phénomènes occultes. Paris: Ed. Montaigne, 1939.

KUHN, Thomas S. Structure of Scientific Revolutions (1962). Chicago: University of Chicago, 1996.

LOPES DE SÁ, Antonio. Ética profissional. São Paulo: Atlas, 1996.

LOPES DE SÁ, Antonio. Fundamentos da contabilidade geral: Introdução ao conhecimento prático e doutrinário da ciência contábil moderna. 5. ed. Curitiba: Juruá, 2017.

LYAS, Colin. Accounting and language. In: MUMFORD, Michael J.; PEASNELL, K. V. (Eds.). Philosophical perspectives on accounting. London: Routledge, 1993. pp. 156-176, 1993.

MACEY, David. The penguin dictionary of critical theory. London: Penguin, 2000.

MARTINS, Eric Aversari. Pesquisa contábil brasileira: Uma análise filosófica. Tese (Doutorado em Controladoria e Contabilidade) - Faculdade de Economia, Administração e Contabilidade da Universidade de São Paulo - USP, SP, Brasil, 2012.

MASI, Vincenzo. La Ragioneria nell'età medievale. Bologna: Tamari.1975.

MAY, George O. Principles of accounting. Journal of Accountancy, p. 423-425, 1937.

MORA, José Ferrater. Dicionário de filosofia. 2. ed. São Paulo: Loyola, 2004.

NIYAMA, Jorge Katsumi; SILVA, César Augusto Tibúrcio. Teoria da Contabilidade. 3. ed. São Paulo: Atlas. 2013.

NOBES, Christopher; PARKER, Robert B. Comparative International Accounting. 11th ed. UK: Pearson, 2010.

NUNES, André. Economia e ideologia: Notas de aula de um curso de introdução à economia política. Curitiba, PR: CRV, 2012.

PAOLINI, Antonella; SOVERCHIA, Michela. Financial Valuations at the beginning of the twentieth century in Italy. In: ALEXANDER, David; ADAMO, Stefano; DI PIETRA, Roberto; FASIELLO, Roberta (Eds.). The history and tradition of Accounting in Italy. London: Routledge, 2017.

PARKER, R. H., NOBES, O. W. 'True and Fair': A survey of UK financial directors. Journal of Business Finance \& Accounting, v. 18 , n. 3 , p. 359-375, 1991. DOI: https://doi.org/10.1111/j.14685957.1991.tb00600.x 
PERAGALLO, Edward. Origin and evolution of double entry bookkeeping: A study of Italian practice from the fourteenth century. New York: American Institute Publishing Company, 1938.

PEREIRA, Oswaldo P. Ciência e dialética em Aristóteles. São Paulo: Editora UNESP, 2001.

PIAGET, Jean. A equilibração das estruturas cognitivas. Rio de Janeiro: Zahar, 1975.

PIAGET, Jean. Seis estudos de Psicologia. Rio de Janeiro: Ed. Forense-Universitária, 1999.

PIPER, Arthur. Graham Ward, CBE, FCA: A matter of principles; IFAC's president says that convergence of international accounting and audit standards requires a change in the US legal climate. Internal Auditor, $v$. 62, n. 5, p. 62-67, 2005.

RIAHI-BELKAOUI, Ahmed. Accounting Theory. USA: Cengage Learning Emea, 2004.

RICHARD, Jacques; COLLETTE, Christine. Système Comptable Français et Normes IFRS. 7. ed. Paris: Dunod, 2005.

ROUTLEDGE. Concise Routledge encyclopedia of philosophy. London: Routledge, 2000.

RYAN, Bob; SACPENS, Robert W.; THEOBALD, Michael. Research method and methodology in finance and accounting. Londres: South Western, 2002.

RUTHERFORD, B. A. The true and tair view doctrine: A search for explication. Journal of Business Finance \& Accounting, v. 12, n. 4, p. 483-494, Winter. 1985. DOI: https://doi.org/10.1111/j.1468-5957.1985.tb00788.x

SANGSTER, Alan; SCATAGLINIBELGHITAR, Giovanna. Luca Pacioli: The father of accounting education. Accounting Education, v. 19, n. 4, p. 423-438, 2010. DOI: https://doi.org/10.1080/09639284.2010.501955

SARGIACOMO, Massimo; CORONELLA, Stefano; MIO, Chiara; SOSTERO, Ugo; DI PIETRA, Roberto. Accounting culture in venice through the lenses of the centuries: An introductory view. In: SARGIACOMO, Massimo; CORONELLA, Stefano; MIO, Chiara; SOSTERO, Ugo; DI PIETRA, Roberto (Eds.). The origins of accounting culture: The Venetian connection. London: Routledge, 2018. pp. 11-28.

SECURITIES AND EXCHANGE COMMISSION (SEC). Study Report Pursuant to Section 108(d) of the Sarbanes-Oaxley act of 2002. USA: SEC, 2003. Disponível em: https://www.sec.gov/news/studies/principlesbasedstand.htm. Acesso em: 23 jun. 2018.

TOMKINS, Cyril; GROVES, Roger. The everyday accountant and researching his reality. Accounting, Organizations and Society, v. 8, n. 4, p. 361-374, 1982. DOI: https://doi.org/10.1016/0361-3682(83)900491

VYGOTSKY, Lev. S. Mind in society: The development of higher psychological processes. Cambridge. MA: Harvard University Press, 1978.

VYGOTSKY, Lev. S. Teoria e método em psicologia. São Paulo: Ed. Martins Fontes, 2004.

VOLTAIRE, François Marie Arouet. Essais sur les mœurs et l'esprit des nations. Paris: Chês Lefêvre Librarie Werdet \& Lequien Fils, 1829. Disponível em: http://classiques.uqac.ca/classiques/Voltaire/essai_sur_les_moeurs_t1/voltaire_essai_sur_les_moeurs_t1.pd f. Acesso em: 25 ago. 2019.

WADSWORTH, Barry. Inteligência e afetividade da criança. 4. ed. São Paulo: Enio Matheus Guazzelli, 1996.

WITTGENSTEIN, Ludwig. Philosophical investigations. 2. ed. London: Basil Blackwell, 1953.

WITTGENSTEIN, Ludwig. Tractatus Iogico-philosophicus. Original version $1921,7^{\text {th }}$ reprint. London: Routledge, 2013.

WOOD, Philip R. Law and practice of international finance. London: Sweet \& Maxwell, 1980. 


\section{NOTAS}

\section{AGRADECIMENTOS}

Ao Congresso Internacional de Contabilidade e Governança da Universidade de Brasília - CCGU/UnB pelo aceite e contribuições de melhoria apresentadas ao presente artigo.

\section{CONTRIBUIÇÃO DE AUTORIA}

Concepção e elaboração do manuscrito: V. R. F. Oliveira; J. K. Niyama

Coleta de dados: J. K. Niyama; V. R. F. Oliveira

Análise de dados: V. R. F. Oliveira; J. K. Niyama

Discussão dos resultados: S. ludícibus; I. M. Beuren; V. R. F. Oliveira; J. K. Niyama

Revisão e aprovação: I. M. Beuren; S. ludícibus; J. K. Niyama

\section{CONJUNTO DE DADOS DE PESQUISA}

Todo o conjunto de dados que dá suporte aos resultados deste estudo foi publicado no próprio artigo. FINANCIAMENTO

Não se aplica.

\section{CONSENTIMENTO DE USO DE IMAGEM}

Não se aplica.

\section{APROVAÇÃO DE COMITÊ DE ÉTICA EM PESQUISA}

Não se aplica.

\section{CONFLITO DE INTERESSES}

Não se aplica.

\section{LICENÇA DE USO}

Os Direitos Autorais para artigos publicados neste periódico são do autor, com direitos de primeira publicação para a Revista. Em virtude de aparecerem nesta Revista de acesso público, os artigos são de uso gratuito, com atribuições próprias, em aplicações educacionais, de exercício profissional e para gestão pública. A Revista adotou a licença Creative Commons Atribuição 4.0 Internacional - CC BY NC ND. Esta licença permite acessar, baixar (download), copiar, imprimir, compartilhar, reutilizar e distribuir os artigos desde que com a citação da fonte, atribuindo os devidos créditos de autoria. Nesses casos, nenhuma permissão é necessária por parte dos autores ou dos editores. Autores têm autorização para assumir contratos adicionais separadamente, para distribuição não-exclusiva da versão do trabalho publicada nesta revista (ex.: publicar em repositório institucional ou um capítulo de livro).

\section{PUBLISHER}

Universidade Federal de Santa Catarina. Curso de Ciências Contábeis e Programa de Pós-graduação em Contabilidade. Publicação no Portal de Periódicos UFSC. As ideias expressadas neste artigo são de responsabilidade de seus autores, não representando, necessariamente, a opinião dos editores ou da universidade.

\section{EDITORES}

Carlos Eduardo Facin Lavarda e Suliani Rover

\section{HISTÓRICO}

Recebido em: 07/09/2019 - Revisado por pares em: 15/04/2020 - Reformulado em: 22/04/2020 Recomendado para publicação em: 12/05/2020 - Publicado em: 30/05/2020

Uma versão preprint do artigo foi apresentada no $4^{\circ}$ Congresso Internacional de Contabilidade e Governança da Universidade de Brasília (4º CCG UnB), 2018. 